\title{
Heroic Masculinity in Post-Soviet Ukraine: Cossacks, UPA and "Svoboda"
}

\author{
Tetyana Bureychak \\ Visiting Fellow, Centre of Gender Excellence, Linköping University \\ Olena Petrenko \\ Lecturer at the Chair of East European History, Ruhr University, Bochum
}

\begin{abstract}
Revisiting the national past and searching for new heroes has become a common trend in many post-communist states, including Ukraine. An aspect that commonly remains invisible when imagining national heroes is gender. Cossacks and fighters of the UPA (Ukrains'ka povstans'ka armiia; Ukrainian Insurgent Army) exemplify some of the most common historical models of Ukrainian heroes. Although the two warrior groups represent rather different historical periods and are treated as national heroes in different ways, this paper seeks to uncover commonalities between them, while pointing out their specificities. In particular, the analysis here looks at the mechanisms that mythologize and naturalize Cossacks and the UPA as an integral part of the current discourses on national identity and hegemonic masculinity. Separately, we focus on the role played by the far-right party, the All-Ukrainian Union "Freedom" ("Svoboda") in these processes. The paper also addresses broader processes of renegotiation of the national historical narrative and promotion of its androcentric heroic version, which strengthen gender neotraditionalism and social hierarchies in post-Soviet Ukraine.
\end{abstract}

Keywords: Masculinity, Cossacks, Ukrainian Insurgent Army (UPA), Gender

Justification of a new national discourse often includes the (re)invention of national heroes, both individual and collective. National heroes project an aura of vigour and invincibility for the whole nation. They set the framework for a collective identity and a shared value system. An aspect that commonly remains invisible in this hegemonic imagining of national heroes is gender. The masculine embodiment of heroes is taken for granted; they are addressed as men and common sense dictates an assumption of their masculinity. In most cases, the national heroes are seen as men of a particular kind (e.g.,

\footnotetext{
* We would like to thank Anton Shekhovtsov, Oksana Kis, Oleh S. Ilnytzkyj and the anonymous reviewers for their constructive advice, and Anya Kateff and Sandra Hawrylchak for their assistance in proofreading and editing.
} 
white, able-bodied, middle-aged, heterosexual, representatives of the titular ethnic group, etc.). This perception not only reflects, but also helps to reinforce the established social hierarchies and inequalities. It becomes an obstacle to establishing a sense of national belonging and citizenship for anyone who differs from the embodiment of the national ideal.

The idea that nation, race, gender and sexuality are socially constructed and that they frequently play an important role in defining each other has been discussed and tested in a large body of research. Some of the important publications in this field include Nira Yuval-Davis' Gender and Nation and such edited volumes as Gender Ironies of Nationalism: Sexing the Nation (Mayer) and Nation and Gender in Contemporary Europe (Tolz and Booth). By focusing on nationalist practices and ideologies that reproduce gender and sexual hierarchies (as well as encourage control and repression), most of these studies primarily discuss women's experiences, leaving masculinity either out of the analysis or treat men as a rather homogeneous social group that benefit from a range of institutional privileges. A similar research focus is common to the small number of studies on gender and nationalism in the Ukrainian context (Kis, Modeli...; Kis, Choosing...; Rubchak). Meanwhile, as Nagel notes, since nationalism, state power, citizenship and militarism are all best understood as masculinist projects, any examination of gender in politics that limits itself to women's experiences misses a major way in which gender shapes politics, namely "through men and their interests, their notions of manliness, and masculine micro and macro culture" (Nagel 243). In developing this idea, our research paper aims to address the under-problematization of men, masculinity and power in existing literature on nationalism, politics and gender by explicitly exploring the mechanisms that construct and legitimize concepts of men and masculinity within the nationalist discourse of contemporary Ukraine. This research draws attention to the symbolic reproduction of cultural ideals of masculinity. It is theoretically inspired by the concept of hegemonic masculinity developed in the works of Connell, Lee, and Messerschmidt. In this study, hegemonic masculinity is referred to as a dominant discourse of masculinity, which legitimizes the hegemony of men, and frames-institutional, symbolical and practical-understandings of culturally approved manhood.

Revisiting the national past and searching for new heroes has become a common trend in many post-communist states, including Ukraine. In situations of political instability and epistemological anarchy, a (re)construction of national history to legitimize new ideologies and new, shared identities often occurs. Despite more than twenty years of 
state independence, the Soviet past remains a significant reference point in Ukraine. Hence a backlash against the Soviet period tends to exaggerate the attractiveness of the pre-Soviet past and glorifies historical struggles against the Soviet regime and Russian imperialism in particular.

The collapse of the Soviet system, which has rendered the normative gender canons irrelevant, has contributed to the emergence of other alternative models of masculinity in the post-Soviet era. The Soviet emancipation discourse and gender norms were criticized as having been coercive and inadequate, and the attempts to create a 'new Soviet man' and a 'new Soviet woman' were seen as brutal experiments that had set out to ruin natural relations between genders (Bureychak Zooming...; Zdravomyslova and Temkina). In the light of national building processes, restoration of traditional gender relations has often been presented as a way to revitalize the Ukrainian nation, to preserve the family, and to renew moral traditions that the Soviet system had destroyed. It has resulted in the growing legitimization of men's dominant position in the public sphere and encouragement of women's displacement into the private sphere. This tendency, which is also typical of other post-communist and post-socialist countries, is sometimes discussed as gender neotraditionalism or a "patriarchal renaissance" (Attwood; Watson; Zdravomyslova and Temkina).

The ideology of nationalism constructs its own system of values and norms, where gender ideals and relationships receive specific understanding. The national models of Ukrainian femininity and masculinity, which have become popular in the post-Soviet Ukraine, are based on rather distinct roles and positions of women and men in society. While the national ideal of femininity stresses motherhood and the spirituality of the family guardian Berehynia (Kis, Choosing...), the national ideal of masculinity emphasizes militarism, courage, male bonding and independence-all of which are inspired by historical examples of hero-warriors, such as Cossacks and fighters of the UPA (Bureychak, Zooming...). This can be illustrated by the growing popularity of these characters in mass-culture (e.g., new films, TVshows, books and songs dedicated to Cossacks and UPA themes), as well as in historical research (the large number of articles and books, $\mathrm{PhD}$ theses on Cossacks and the UPA), which together form the dominant national narrative in post-Soviet Ukraine (Bureychak, Cossacks...; Bureychak, In Search...).

As this article demonstrates below, one can see a radicalization of the national understanding of masculinity in recent years by far-right groups and organizations. The far-right party, the All-Ukrainian Union 
"Freedom" ("Svoboda") is one of them. Svoboda entered Ukrainian parliament in 2012, but, more recently (2014), failed to pass the 5 percent electoral threshold and presently holds no seats in Parliament. The party is guided by a pronounced nationalist model of heroic masculinity, which turns toward strong and persistent men, represented by historical Cossacks and fighters of the UPA (Ukrains'ka povstans'ka armiia; Ukrainian Insurgent Army). Although the two warrior groups represent rather different historical periods and are treated as national heroes in different ways, this paper seeks to uncover commonalities between them, while pointing out their specificities. In particular, the analysis here looks at the mechanisms that mythologize and naturalize Cossacks and the UPA as an integral part of the current discourses on national identity and hegemonic masculinity.

The paper begins with a presentation of the current discourses on Cossacks and the UPA in relation to masculinity. The following section focuses on how the concept of heroic and historical masculinity is an integral part of Svoboda's ideology. The paper concludes with a discussion of the appeal and relevance of the heroic ideal of masculinity for the dominant versions of the national narrative in post-Soviet Ukraine. The paper will make only passing reference to the dramatic events of the Euromaidan and the war in the Donbas.

\section{Cossacks: Heroes of THE PAST AND THE PRESENT}

The military community of Cossacks that played an important role in European geopolitics and in Ukrainian history from the fifteenth to the seventeenth centuries (Wilson; Plokhy; Kappeler), has now become one of the central elements of the contemporary Ukrainian national imagination. Glorifying Cossacks as Ukrainian heroes dates back to the beginning of the Ukrainian national revival in the first half of the nineteenth century (Saltovs'kyi). Admiration for them was initially expressed among a small number of educated Ukrainian nobility and propagated in Ukrainian literature. Some of the most significant works by Ivan Kotliarevs'kyi, Mykola Hohol' (Gogol') and Taras Shevchenko refer to Cossacks, and have since become classics. Most of these texts depict Cossacks as brave, strong, independent and patriotic warriors who fight against Russian tsarist rule and Ukraine's autonomy. The epoch of the Ukrainian Cossacks was generally downplayed in Soviet historiography due to fears that it might incite nationalistic and separatist feelings among Ukrainians. As a result, this model of masculinity was not widely promoted and therefore had no chance to gain popularity. Partial rehabilitation of Cossack's legacy was connected 
to the search for positive heroic images during the Second World War, with the figure of hetman Bohdan Khmel'nyts'kyi becoming one of the most prominent (Yekelchyk 20-23).

The post-Soviet period of Ukraine evidences a new wave of interest in Cossacks, characterized by their celebration as national heroes and resulting in their promotion in a variety of ways. Some forms of democracy that were unique to the Cossacks have fuelled current populist claims for the re-establishment of longstanding democratic traditions that purportedly prove the similarities between Ukraine and Western democracies (Miahka; Kondratiuk). Establishing continuity with the Cossack period is officially presented as a foundation for a new, shared Ukrainian identity (Neubert). Emulation of the spiritual qualities of Cossacks is encouraged as a way to prove one's patriotism and devotion to national values and Ukrainian sovereignty. The discourse around Cossacks has been integrated into socialization practices, sport, popular and consumer culture, grass-roots Cossack communities and official state pronouncements and initiatives (Bureychak, Cossacks...; In Search...; Zooming...). State elites and institutional representatives of state power play a key role in legitimizing such narratives. Since 1991, Cossacks have become a central element in the state's version of the national ideology. They are among the official symbols and images of Ukraine, promoted and represented in the anthem of Ukraine, in symbols of presidential power and in banknote iconography, to name only a few examples.

"Ukraine has not yet perished" (based on lyrics by P. Chubyns'kyi and music by M. Verbyts'kyi) has been the official anthem of Ukraine since 1992. The text refers to the Cossack epoch and the long struggle of the Ukrainian people for independence and their hopes for defeating their enemies and regaining sovereignty over the country. The spiritual and physical dedication to this aim includes the desire to prove Cossack lineage. The anthem addresses the people of Ukraine not only as Cossacks, but also as brothers. It articulates and naturalizes the importance of Ukrainian men in making history, nation building, fighting enemies, ruling the country and being heroes.

As mentioned, references to Cossacks are also present in the official symbols of the President of Ukraine, which include four objects: the president's standard (flag), collar, official stamp and mace (bulava). The official website of the President of Ukraine explains that the symbols of the highest power are usually unique historical artifacts. Two of themthe collar and mace-refer to the Cossack period. The collar of the president, apart from the elements added by modern artists, contains an amulet, which allegedly belonged to hetman Ivan Mazepa. Another 
symbol of the president-the mace-originally a cold weapon, has historically served as an attribute of power of Cossack hetmans. Although the symbols of the president are not integrated into the routine of daily life, they are nevertheless important ideological signifiers that are encouraged by, and identified with, the state.

Banknote iconography is another way for the state to construct an image of the nation for its own citizens and foreigners (Hymans, "International Patterns..." 317). Due to the variety of national symbols, a state faces a tough choice when trying to prioritize what to include on a banknote. The state, in this case, plays the role of "national pedagogue" (Gilbert and Helleiner 3-9; Hymans, "The Changing Color..."), using money as a vehicle for spreading national values and images of national heroes among the entire population. Cossacks are part of the visual layout of the Ukrainian national currency in two out of eight banknotes.

Apart from integrating Cossacks into the official state image, the Ukrainian government has undertaken a number of initiatives to support the development of the contemporary Cossack movement and to promote commemorative policies that glorify the Cossack period. Sixty legislative acts promoting Cossacks were passed by the highest representatives of state power in Ukraine, i.e., the President, the Cabinet of Ministers, and Parliament (Verkhovna Rada) during the period 19912011 (Bureychak Zooming...).

The Day of Ukrainian Cossackdom, October 14, which is also a major holiday within the Eastern Orthodox tradition-i.e., the Intercession of the Theotokos (Pokrova) — was recognized as a state holiday in 1999 and the President of Ukraine typically offers on this day a celebratory address to contemporary Ukrainian Cossacks and the entire Ukrainian people. The Holy Virgin is known to be a guardian and patroness of the Cossack community and the Day of the Pokrova has been one of the most important Cossack holidays. This joining of Cossack and Christian values, both of which are known to be highly conservative in terms of gender norms, promotes further strengthening of the androcentric version of the current national discourse.

The attraction of Cossacks is such that politicians and political parties employ it to ensure public support. For example, a new political party-Cossack People's Party (Kozats'ka narodna partiia)—was registered in 2010 , having become the $185^{\text {th }}$ political party in Ukraine.

Individual as well as collective actors also promote a glorified image of Cossackdom. The Cossack has become an ideal for the socialization of boys, through the proliferation of the "combat hopak" (boiovyi hopak), a combination of dance and martial art, which is promoted as allegedly 
authentic. Cossack imagery is also used for the branding and/or marketing of Ukrainian consumer products.

The development of Cossack organizations and institutionalization of the Cossack movement is another common trend in post-Soviet Ukraine, although the functioning of Cossack organizations in Ukraine is far from harmonious. Apart from disagreement on formal issues (such as the procedures of membership, Cossack uniforms, ranks, awards, etc.), there is conceptual discord as to understanding Cossackdom in terms of its loyalty to the state, its attitude toward Ukraine's independence, language, religion, not to mention its relationship to other Cossack organizations in Russia and elsewhere (Bureychak, Zooming...). Although public perception of Cossacks has its regional specificity, the integration of Cossackdom into the dominant state ideology contributes to levelling these differences and results in their evaluation as exclusively positive national heroes.

Contemporary references to Cossacks within academic research and publications tend to disregard gender aspects, despite the fact that historically it was predominantly a male military community. Although some Cossacks had families, and women were occasionally a part of Cossack settlements and even participated in military actions (Kryvoshyi), the role of women in Cossack life was marginal. Wars and military actions privileged physical strength, the ability to fight and use weapons, which inevitably reinforced the masculine military ethos and the subordination of women. A contemporary image that complements the Cossack is the Berehynia: a rather abstract embodiment of traditional femininity, a guardian of family and nation, derived from Slavic mythology. Some Cossack organizations, which occasionally may have female participants, will typically assign women the role of Berehynia in order to preserve Cossack culture, sing Cossack songs and represent the community during Cossack festivals.

Very few nations posses such an illustrious embodiment of national heroes as does Ukraine in the case of the Cossacks. The availability of historical characters that played an important role in the nation's history enables their inclusion in the national imagination and helps to frame a shared and continuous identity. Pride and empowerment are important messages of the Cossack discourse. The ideals of masculinity and national identity suggested by the Cossacks can be seen as reaction to the weakening or the 'feminization' of men, referred to sometimes as the "late Soviet crisis of masculinity" (Zdravomyslova and Temkina), as well as the colonization of the Ukrainian nation during the Soviet era. Given this recent past, the model of the Cossack suggests male empowerment, the regeneration of the nation on foundations of "true" masculinity. At 
the same time, the representation of Cossacks as national heroes contributes to the promotion of a masculine concept of nation, a false sense of homogeneity in terms of gender, ethnic affiliation and citizenship. Finally, it leads to symbolic and actual exclusion of women from politics and the public sphere.

\section{Great Men In the National NaRRative: The CASE of Roman ShUKhEVych}

As in many other cases that illustrate the processes of nation building, gender representations of the history of the Ukrainian nationalist underground reflect typical schemes in which situational femininities and masculinities are realized and which legitimize and reinforce the struggle for nationhood (Enloe, Yuval-Davis). In the case of hegemonic masculinity, to use the terminology of Robert W. Connell, it is the underlining, heroization and popularization of the militaristic masculinity that take a significant place in the representation of the history of the OUN and UPA. ${ }^{1}$ The concept of men as defenders, as strong, undefeatable warriors, has gained attention and respect. According to Connell, marginalization and tabooing do not necessarily affect only women. Authoritarianism and hierarchical structures are also characteristic of various masculinities (Connell, Gender and Power, 183191).

1 The Organization of Ukrainian Nationalists (OUN) was created in Vienna in 1929, with Ievhen Konovalets' as the first commander. The primary goal was to gain independence for Ukraine, a struggle that was often conducted through acts of sabotage, expropriations and assassinations. In 1940, the OUN split into the OUN-M (an older and more moderate group supporting Andrii Mel'nyk) and OUN-B (a younger and more radical membership supporting Stepan Bandera). The OUN-B declared an independent Ukrainian state in June 1941, an act that was not coordinated with Nazi authorities. In response, the Germans arrested the OUN leaderships. After this, the Ukrainian Insurgent Army fought against both Nazi Germany and the Soviet Union, the latter war continuing well into late 1950s. The Ukrainian rebels became one of the Soviet regime's main enemies. Under these conditions, the Ukrainian insurgents adopted a strategy of the "deep underground," which became known as "the bunker war." The struggle of the OUN and the UPA was marked by widely practiced violence, which involved terrorist activities, retaliation against communists and their families, and antiPolish pogroms. This brutality is one of the crucial factors that have contributed to the present ambivalent assessments of Ukrainian nationalist activity in Volyn and East Galicia from 1929 to the 1950s. For details, see Bruder; Kentii; Kulchyts'kyi; Litopys Ukrains'koi Povstans'koi Armii; Litopys UPA. Nova Seriia; Marples; Motyka; Rudling; Viedienieiev and Bystrukhin. 
In the context of the nation-forming processes, marginalization and subordination, as a rule, become a burden for men who do not correspond to the 'standards' of a 'real' man, a fighter for his nation. Based on examples from Ukrainian national historiography, this section will show which 'standards' served as a basis for hegemonic masculinity in the Ukrainian nationalistic underground. Who exactly, and under what circumstances, served in the role of 'great men' in the OUN and the UPA in post-Soviet Ukraine, and who remained on the margins of the national memory, failing to pass 'the standards control' for entering the pantheon of 'great heroes'?

The change in the political situation in Ukraine and the opening of archives in the early 1990s led to a real boom in the history of the OUN and the UPA, contributing to a radical revision of Soviet views. The image of former "traitors" has been significantly revised. The transition from a Soviet description of history to a new "national paradigm" was described by Serhii Yekelchyk as a movement "from the old orthodoxy to the new": "The 'national paradigm' of Ukrainian history - a grand narrative focusing on the Ukrainian ethnic nation's struggle for its own state, replaced the Soviet models of 'socialist construction' and 'friendship of peoples' with a similar sort of dogmatism" (Yekelchyk, Bridging the past... 560). According to Yekelchyk, this dogmatism was first of all formed by the understanding of the nation as a subject of history and the dominant ethno-national approach in historical description.

As part of these massive transformations, the project of creating a new hegemonic masculinity played a significant role: the image of "an undefeatable and unvanquished fighter" for Ukraine's freedom attained discursive privileges and started to be widely used both in commemorative practices when honouring members of the Ukrainian nationalist underground, as well as in the mass media, and in the nation's historiography. A good example of this is the representation of the image of the supreme commander of the UPA, Roman Shukhevych, which became a "standard" of sorts for identifying the ideal of "the new great men" in the national narrative. To make the point, we will examine some biographical essays about Shukhevych that were published in Ukraine within recent years.

Alongside with essays dedicated to other prominent functionaries of the Ukrainian nationalist underground (see, Litopys UPA Online), the figure of Roman Shukhevych gained special popularity due largely to the glorification of UPA history during the presidency of Viktor 
Yushchenko. ${ }^{2}$ The conventional portrait of the UPA commander is generally stripped of critical reminiscences and testimony. ${ }^{3}$ Instead, it is focused on the heroic deeds of his youth, his organizational talents and extraordinary personality.

Describing the childhood of the future commander, the historian Mykola Posivnych, an author of several biographical essays about members of the nationalist underground, insists that Shukhevych "inherited the best features of his relatives and the Galician intelligentsia in general, namely patriotism, intellectuality, a high level of culture in his attitude toward himself and his entourage" (Posivnych, Roman Shukhevych 6). The author describes the UPA leader as "an outstanding and vivid personality..., a well-educated, gifted and talented organizer, a highly respected leader, a military commander..., a vivid example of a strong and purposeful personality" (Posivnych, Roman Shukhevych 59). The prominent historian Volodymyr Serhiichuk drew parallels between Prometheus and the UPA commander:

[Shukhevych] could not deviate from the path of struggle that he had chosen, for he not only had a conscience, a sense of duty toward those

\footnotetext{
2 The first attempts to revise the Ukrainian national narrative already took place at the end of the Soviet era. The pro-independence movement Rukh, which received strong support in western Ukraine, raised the question of rehabilitating the OUN and the UPA. In April s1991 the Ukrainian parliament passed a law, On the Rehabilitation of Victims of Political Repressions in Ukraine. Although it did not yet include the UPA or the OUN as groups to be rehabilitated, it was one of the first official attempts to reread Ukrainian history (Shevel 148). The most significant period of glorification of the UPA began with Viktor Yushchenko's presidency in 2005. In 2007 and 2010, respectively, Roman Shukhevych, the supreme commander of the UPA and Stepan Bandera, the head of the OUN-B, received the titles of "Hero of Ukraine." The Donetsk district administrative court of appeal invalidated the title for Shukhevych in April 2010. The Supreme administrative court of Ukraine supported the latter decision in 2011 in relation to both Shukhevych and Bandera ("Sud zalyshyv...").

3 For example, see Oleksandr Luts'kyi's transcripts of the investigations of member of Provid (i.e., the UPA leadership). Luts'kyi stresses that the majority of the members of Provid, including Vasyl' Kuk, were predisposed against Shukhevych (Luts'kyi). Kateryna Zaryts'ka, Shukhevych's messenger and close friend, who was also arrested by Soviet Security Services, pointed to the confrontation between Kuk and Shukhevych. According to her, Shukhevych often complained of Kuk's own initiatives. The latter, according to other evidence, ordered the removal of the slogan "Long live the UPA Commander, Taras Chuprynka" from propagandistic documents (See, Viedienieiev, Odisseia Vasylia Kuka... 49).
} 
who believed in the future of an independent Ukraine on their own soil, but also found it important to prove to the whole world that Ukraine had not yet perished... He knew that a [nationally] conscious Ukraine viewed him and his companions-in-arms as "staunch fighter-knights for the great truth," fighters for a great idea, as the blacksmiths of a bright future. He knew that people believed in him on his native land, including those Ukrainians who had been forced from it by wicked fate... That was why he remained in the vanguard of the Ukrainian liberation movement, like a chained Prometheus. (Serhiichuk 18)

Other authors emphasized that Shukhevych was handsome, dropping hints that women easily fell in love with him (Shtokalo, Trofymiak 245).4 Sexual attraction, of course, is an important component in the identity of a great warrior. At the same time, Shukhevych's romances and love trysts are modestly removed from the narratives. The sexuality that is produced, with certain modifications, is amorphous and standardized, that of "a legitimate couple," with the woman in the role of bride or wife. Sexuality is represented in terms of continuity of the kin, whereas the narrative itself remains in the secure zone of existing, fixed 'laws and regulations.' Tetiana Antonova, who described the women of Roman Shukhevych in her research, made a peculiar step forward. "It was intrinsic of him, as is common for all men, to take a woman as an aesthetic and erotic object. However, he managed to see their other qualities. First of all, he evaluated a woman's appearance, then her intellect" (Antonova, Zhinky v zhytti... 247). This article, typically, leaves out mentioning Shukhevych's love affairs, deferentially remarking about the commander's wife: "Whether Natalia knew that she was not likely to be her man's only woman, we may only guess" (255) - and then once again appeals to the steadfastness of women who were close to the leader. However, Antonova's text, mostly unintentionally, also offered quite an unattractive portrait of the UPA commander. Shukhevych is shown sneering at the dreams of one of his messengers, makes numerous sexist jokes, and, taking into account his constant remarks about his love for women, does not really practice devotedness to his wife. Antonova emphasizes that rank and military uniform attracted women and, as a result, Shukhevych "received double

\footnotetext{
4 This is well reflected in a film about Shukhevych, Neskorenyi (The Undefeated, 2000). The film portrays Shukhevych as the embodiment of ideal masculinity and the plot follows a traditional pattern in depicting masculinity and femininity. In the opening episode, viewers see a well-built commander of the UPA going for a swim. His messenger, Halyna Didyk, looks on at him from the shore with admiration.
} 
the attention from the side of women. They loved him and he obviously responded to their feelings" (Antonova 255).

All of these texts depict Shukhevych as an exclusively positive person. Surely, however, the image of Roman Shukhevych as the "great man" can hardly be ascribed to him alone since there were other prominent leaders in the underground as attested by their regalia and positions. Any man who neglected his family, showed fear on the battlefield, appeared physically weak, or was ignored by his subordinates could not, by definition, become a model for imitation.

\section{SVOBODA'S GENDER NARRATIVES}

In contrast to many European countries, Ukraine has mostly excluded far-right parties from Parliament. They have remained politically marginal and have not enjoyed broad popular support during most of the period of Ukraine's independence since 1991. The situation changed in 2012, when Svoboda entered Parliament with the fourth highest number of deputies (37 out of 450). At the time this was the greatest political breakthrough of the far right in Ukraine, and was preceded by Svoboda's success in regional council elections several years earlier. The party won 50 seats (out of a total of 120) in the Ternopil regional council in 2009 and 41 seats (out of a total of 116) in the Lviv regional council in 2010. Despite significant geographical differences in their public support (limited mostly to western Ukraine), the fact that Svoboda entered Parliament seemed to suggest that the far right was winning legitimacy and increasing its influence at the national level. Despite the fact that Svoboda fell short of the five percent threshold in the October 2014 election (thus failing to enter the new Parliament), it represents an interesting case for the study of gender issues in Ukrainian politics today.

Like many far-right parties, the ideology of Svoboda is grounded in nativism, i.e., a political position demanding favoured status for traditional inhabitants of the nation rather than immigrants. The party is also populist, staking out an anti-elitist position and claiming to represent the will of the people (Mudde, Three Decades... 8). The ideology of the party is reflected in its programs, published texts and the public speeches of its leaders. These paint a picture of a nation under threat, citing Ukraine's most dangerous enemies (e.g., communists, migrants, Jews, ex-KGB cadres, etc.) as well as social processes (e.g., Ukrainophobia, the political and economic influence of Russia, moral dissoluteness, the demographic crisis, poor health of the population, occupation of Ukraine by foreign media). The party claims for itself a 
missionary role in fighting these evils and in bringing peace and order to the country. In this respect, the title of the party's platform, "The Program for the Protection of Ukrainians (Prohrama zakhystu ukraintsiv)," is symptomatic ("Prohrama V0 'Svoboda' ..."). ${ }^{5}$

Legitimization of Svoboda's ideology is accomplished by parallel references to two mutually reinforcing and conservative themes. One is the nation's past (especially the Cossack epoch and the nationalist struggle of OUN-UPA) and the need to revive its heroic spirit and traditions. The other one is religion, more specifically, Christianity. Consistent reiteration of religiosity as a central component of national belonging contributes to identifying the party's ideology and practices as something that is both moral and noble. Svoboda's major motto is: "We are in our own, God-given country," which is also an acronym of its name: Ми - у СВОїй, БОгом ДАній країні (“Prohrama VO 'Svoboda'...”). Thus, discursively, it connects Christianity to national identity and implies that religion confers its blessing on Svoboda's vision of the strong state.

It is important to emphasize that Svoboda engages simultaneously in discourses of belonging (unity) and otherness, which are based on a range of intersecting and mutually constitutive identity markers such as class, race, ethnicity, citizenship, religion, gender, sexuality, and ability (Likhachev). However, current research on Svoboda usually neglects gender and sexuality. In fact, explicit references to gender and masculinity issues are not common in studies of the far right, despite the fact that most radical right parties and movements have greater support among males, have more male party members and leaders, and, usually, represent quite distinct conservative gender views when it comes to the roles of men and women, homosexuality and family issues (Kimmel; Mudde). Even more striking is the gender-blindness of research on the far right, which often takes a white, able-bodied male subject and his experiences as the universal norm, thus reproducing masculinity as a non-gendered and politically unproblematic concept. With few exceptions (Chermalykh; Hrytsenko), gender discourses and constructs of masculinity promoted by the far right, and Svoboda in particular, remain poorly studied and are theoretically under-problematized.

Preserving the traditional family is one of the central elements of the patriarchal rhetoric promoted by the majority of far-right organizations, including Svoboda. The importance of the traditional Ukrainian family in

\footnotetext{
5 For more on the specific ideas that are either attacked or defended by Svoboda, see Shekhovtsov; Umland and Shekhovtsov.
} 
the party's ideology can be explained by the fact that Svoboda views the family as an important space for preserving and transmitting Ukrainian national ideology and culture. This was particularly significant during Ukraine's stateless period (Chermalykh 53). Revival of traditional family and gender norms today is seen by the party as a way to regenerate the Ukrainian nation and culture.

There are at least two problems with such reasoning. On the one hand, idealization of gender relations in the traditional Ukrainian family contradicts much of the contemporary historical and ethnographic research, which proves that gender hierarchies, discrimination and violence existed in Ukrainian families in the past (Kis, Zhinka $v$ tradytsiinii...). On the other hand, promotion of the traditional family does not correspond to the reality of contemporary Ukrainian society, with its high involvement of women in public life and the paid labour force, or the prevalence of dual-income households. Promotion of traditional family relations is highly problematic due to the unequal social position of men and women that it accepts. A traditional family implies a rigid hierarchal structure with the subordination of woman and other family members to a strong male figure. This vision of gender relations in the private sphere also affects the hierarchal positioning of men and women in the public realm.

The patriarchal discourse of Svoboda includes several interrelated elements, such as praising motherhood; control of women's sexuality; aggressive rejection of all forms of sexuality other than the heterosexual; and emphasis on contrasting and often hierarchal social roles for men and women, with a particular stress on militaristic heroic masculinity.

The centrality of motherhood for the normative understanding of femininity in Svoboda's ideology is reflected in the party's goal to introduce Mother's Day as an official Ukrainian celebration on the second Sunday of May ("Prohrama VO 'Svoboda'...," Part VI, 18). According to the head of the Svoboda Student organization, Oleksandr Siudak: "Mother's holiday is a symbolic day, since it is mothers who give birth to the future warriors and protectors of the nation... To raise a patriot of the Motherland is a great and sacred matter. That is why taking care of women/mothers is one of the priorities of the nationalist authorities" ("Natsionalisty vitally..."). Ironically this holiday can be considered neither Ukrainian nor traditional, since it was originally established in the USA in 1914. However, the apparent importance of formally celebrating motherhood, as the highest mission of women, blinds Svoboda to this fact and leads it to creatively reinvent Ukrainian traditions. 
Since the purity of mothers must be impeccable, the nationalists often have a vested interest in the control of women's sexuality (Nagel 254), which, in the case of Svoboda, has led to an initiative to ban abortions in Ukraine. ${ }^{6}$ Although this proposed legislation was rejected in June 2013, it contributed to the public debate on motherhood as the highest social mission of women.

Sexuality in nationalist ideology is strongly connected to reproduction. Only heterosexuality is considered an acceptable form of sexual behaviour and identity. Indeed, Svoboda, like most other far-right groups in Ukraine, can be characterized as one of the strongest fronts of homophobia and of sexual intolerance. Svoboda is known for its numerous attacks on various initiatives advocating recognition and protection of the rights of LGBT people (e.g., "Natsionalisty 'pokaraly zbochentsiv-pederastiv'...). It is also one of the most ardent proponents of banning the "propaganda of homosexualism" in Ukraine. Svoboda deputy Ihor Shvaika invokes the latter, arguing that homosexual values, "ruin Christian positions..., the traditional basis of the family, our Ukrainian unique identity and they lead to undermining of Ukrainian values" ("V 'Svobode' zaiavlyaiut...").

The patriarchal character of Svoboda's ideology is reflected in the prioritization of traditional male spheres (e.g., defense and leadership of the country), male roles (e.g., guardian, patriot, leader, hero) and values (toughness, domination, aggression, brutality, bravery, strength, stoicism, persistence, willpower, independence, fraternity). The Svoboda program devotes a disproportionate amount of attention to questions of defense and military issues, with strikingly little or no consideration for welfare policy, development of social infrastructure and social politics, which are commonly labeled as feminine realms. ${ }^{7}$ Symptomatic also is the male dominance in the party's membership and leadership, not to mention the party's reluctance to support higher political involvement of women. Among the five parties that entered the Ukrainian parliament in 2012 , the representation of women in Svoboda's list of candidates was the lowest (6\%); not a single woman was among its top 25 candidates ("Vybory Narodnykh Deputativ...").

Svoboda repeatedly resorts to the discourse of foreign threats, the need to combat enemies, especially Russia (i.e., Kremlin's imperialism

\footnotetext{
${ }^{6}$ A draft bill, titled Amendments of Selective Legislative Acts of Ukraine (On the Artificial Termination of Pregnancy [abortion]) No. 2646-1 was proposed by Svoboda in April 2013 and rejected by Parliament in June 2013.

7 This can by traced especially in the issues that the party prioritized in its program ("Prohrama VO 'Svoboda'...").
} 
and the so-called "Russian world" [russkii mir]), which are reinforced by the slogans "Glory to the nation! Death to the enemies!"- frequently uttered by party members during street marches ("Na Cherkaschyni...). This aggressive militaristic rhetoric implies that primarily men have the high mission of resisting all dangers and fighting for a better future. Militarism works as an effective mechanism to reinforce traditional (hegemonic) masculinity. The militaristic discourse and actions of Svoboda intensified following Russia's military aggression in Ukraine in March 2014 ("Rezolutiya Z"izdu VO 'Svobody'..."). It actively supported the government's antiterrorist operation in the Donbas ("Doluchuitesia...") and created a special battalion with the symbolic Cossack name "Sich" ("Pro batal'ion...").

Symbolically, the male privilege to lead is reflected in Svoboda's narratives about great national warriors, who are frequently linked to the Cossack and UPA traditions. References to Cossacks and the Hetmanate were integrated into Svoboda's draft version of the Constitution of Ukraine ("Natsional'na Konstytutsiia...") and its Program for the Protection of Ukrainians ('Prohrama VO 'Svoboda'...), where this historical era is mentioned as the origin of Ukrainian state independence ("Independent Ukraine was established as a result of a three hundred year struggle for the national liberation of Ukrainians" ["Prohrama VO 'Svoboda'...'). The idealization of the Cossack period leads to its representation as "an important foundation for traditional spirituality of the Ukrainian nation and for educating youth in the spirit of respect for the heroic past of Ukraine" ("Luhans'ka 'Svoboda'...").

While actively encouraging the revival of Cossack traditions, Svoboda zealously protects the "authenticity" of Cossack organizations and condemns those who do not promote "real" versions, i.e., organizations that are not Ukrainian speaking or those that allow members of non-Slavic descent ("Luhans'ka 'Svoboda'...").

Although Cossacks are well integrated into Svoboda's nationalist narrative, the party's identity appears to be more closely tied to the UPA. In general, there are fewer references to Cossacks in official and public texts, and less interest in celebrating Cossacks events than those related to the UPA. The reasons are twofold. First, Cossacks are now part of mainstream politics, the official national imagination and a symbol of the Ukrainian state (as mentioned above). As such, they are more difficult to re-appropriate for marketing a particular party. Second, Cossacks, unlike the UPA, are much less relevant in Svoboda's anti-Soviet and anticommunist rhetoric.

The uncompromising glorification of OUN's and UPA's activities has made Svoboda one of the most ardent supporters of solidifying a 
national grand narrative. Deputies from Svoboda regularly bring OUN and UPA symbols into Parliament. In the Lviv Regional Council, they demanded that the resolution of the Donetsk Administrative Court of Appeals, which cancelled the Decree of President Yushchenko "On Awarding Bandera the title Hero of Ukraine" be declared illegal. Svoboda's official statement asserted: "The enemies of Ukraine could not defeat Bandera when he was alive. They are afraid of him even after his death. Despite the narrow-minded and worthless court decisions, Bandera was and remains a Ukrainian hero for millions of Ukrainians" ("Luhans'ka 'Svoboda'..."). In October 2013, the party also organized a march in support of the official recognition of the OUN and the UPA as participating combatants in the Second World War. The march demanded support for a law that would equalize the status of OUN and UPA fighters to that of Soviet veterans, giving them the respective benefits.

At the same time Svoboda representatives took an active part in annual solemn events in honour of the Cossacks who perished in the battle of Berestechko. In 2013 during an official speech on the subject, member of Parliament from Svoboda, Oleh Osukhovs'kyi, remarked: "We commemorate the heroes, who were fighting for the freedom of Ukraine. They have perished, but their strivings and ideas have not. The deeds of Cossacks are an inspiration for the struggle even today..." ("Na poli..."). Oleh Pankevych, another deputy from Svoboda, also emphasized:

The battle of Berestechko was one of the glorious pages in Ukrainian history, an example of a self-sacrificing struggle for freedom and independence. I do not agree with those who see this battlefield as a symbol of defeat of our army. The battle of Berestechko is a symbol of striving of Ukrainians for a powerful, proud and mighty state, which our enemies will be afraid of and our neighbours will respect (...) the battlefield of Berestechko is not a place of discouragement and disappointment but a place of a heroic deed that encourages us to continue our struggle." ("Na poli...")

A similar martyrological discourse is employed in relation to the fighters of the UPA. The narratives of these two groups of heroes symbolically intersect on the religious holiday of the Intercession of the Theotokos (Pokrova), October 14, mentioned above. It is also the day the UPA was founded. One of the political goals of Svoboda was to proclaim this day an official state holiday, a day that would replace the Day of the 
Defender of Motherland (February 23), which has been celebrated in Ukraine since Soviet times ("Prohrama VO 'Svoboda'..."). ${ }^{8}$

The symbols, slogans and the history of the OUN, the UPA and the Cossacks received further attention during a new wave of protests in Ukraine, the Euromaidan that began in November 2013. Along with Ukrainian flags, the central square of Kyiv was decorated with the symbols and flags of the OUN and the UPA. The representatives of some Cossack organizations joined the protesters and became the protectors of the Euromaidan, thereby boosting their image as contemporary models. A famous blogger, Arkadii Babchenko, drew direct parallels between the Zaporozhian Sich and the Euromaidan. According to Babchenko, the Euromaidan represented a space that does not recognize any forms of political power but its own. He emphasized that the cornerstone of the barricades were neither the intellectuals, who spent their nights at home, nor the students, but the "simple men," "the Cossacks." (Babchenko).

The Ukrainian male protesters embodied the ideal of a strong, undefeatable and freedom-loving warrior, who, for some, was associated with the militaristic masculinity of the Cossacks, OUN and UPA fighters. Thus, ordinary men had a rare opportunity to approximate the dreams of heroic masculinity. A remarkable example of the symbolic, visual and trans-historical joining of these heroic characters became a photo stand for taking souvenir pictures in the Kyiv city administration building. It showed a Cossack and a fighter of the UPA, standing shoulder to shoulder over a defeated enemy, an officer of the special police force "Berkut" (figure 1).

8 President Petro Poroshenko proclaimed a new state holiday-Day of the Defender of Ukraine-on 14 October 2014. It is formally connected to the Orthodox feast, but even more importantly has symbolic value, given the current political context (i.e., the Euromaidan and Russia's aggression against Ukraine). In this way, present-day Ukrainian soldiers are portrayed as successors of the traditions, history and mythology of the Cossacks and the UPA. The name of the holiday carries a positive discursive connotation, invoking both the defender and the fatherland. It shows the significance of language or terminology in the debates about the Ukrainian nationalist movement. The conflict with Russia, in turn, is producing a new symbolic calendar of commemorations, helping to mobilize the past for the creation of a united Ukrainian identity and a final break with Soviet grand narratives. 


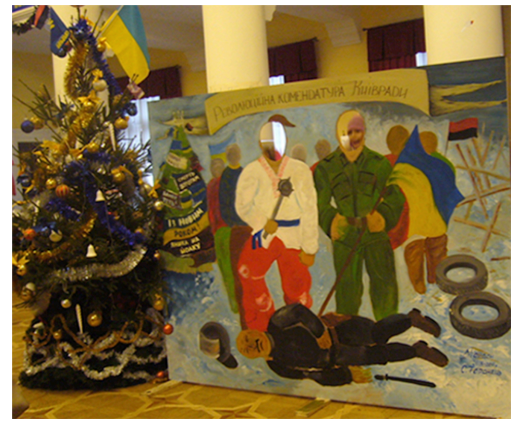

Figure 1. "Revolutionary Headquarters of the Kyiv City Council", Kyiv City Administration Building, 2 Jan. 2014 (Photo by Olena Petrenko).

The Euromaidan promoted strong expectations of and hierarchal relations between men and women (See Bureychak and Petrenko; Philipps 2014; Onuch and Martsenyuk; Martseniuk). Accordingly, men were seen as the defenders and the "driving force" of the nation; women, in contrast, were typically seen as weak, vulnerable and in need of male protection.

\section{CONCLUSIONS}

The current social and political insecurity in Ukraine has become a catalyst for viewing the past as a reservoir of hope, pride and dignity. At the same time, the political re-imagining of the nation promotes the creation of national mythologies. A romanticized and mythologized past, along with its heroes, can potentially become a mobilizing strategy for maintaining purity, uniqueness, homogeneity and gender inequalities.

Despite different levels of integration into the hegemonic national narrative, contemporary discourses about Cossacks, the OUN and the UPA reproduce a similar mythological ideal of masculinity. They do not only provide explanations for perceived victimization of the Ukrainian nation/men, but also mobilize them for common action, as in the case of the truly heroic men on the Euromaidan.

Examples of a glorious Cossack past and of undefeatable UPA fighters have become pivotal narratives in revitalizing Ukrainian traditions. They embody the notions of "real" and "authentic" Ukrainian masculinity and femininity, emphasizing patriotic and militaristic manhood and exalted motherhood. The Svoboda party actively contributes to this. Its members organize and participate in activities commemorating Cossacks and the UPA. The political program of the party contains numerous references to the history of Cossacks. The party activists promote recognition of the UPA as a legitimate participating combatant during the Second World War. The glorification 
of the memory of the OUN and the UPA by Svoboda is connected with its radical anti-Soviet rhetoric and the search for its own counter-heroes.

The dramatic and rapid development of political events in Ukraine connected with the Euromaidan and the ensuing war in the Donbas has considerably raised the significance and relevance of militaristic masculinity in the current context. Ordinary Ukrainian men in real combat situations suddenly exemplify the model of a Ukrainian herowarrior, which was initially promoted only as an abstract ideal in the post-Soviet period. For some members of society and for many male activists of the Euromaidan and the war in the Donbas, the sense of continuity with the OUN, UPA and the Cossack periods brought new meaning to the notions of victimhood, bravery, independence and power. It has become a broader frame of identification for a range of men from the Euromaidan and for Ukrainian soldiers, who previously might not have thought of themselves in such clear national terms. Militaristic masculinity has acquired a particular symbolic meaning due to these circumstances. The concept of men as defenders and warriors has garnered attention and respect. Men have been given the opportunity to emulate and experience the glory of the past Ukrainian heroes. The danger may be that women's roles in this context may be circumscribed.

\section{Works Cited}

Antonova, Tetyana. "Zhinky v zhytti Romana Shukhevycha, holovnoho komandyra Ukrains'koi Povsanskoi Armii." Ukrains'kyi Vyzvolnyi Rukh 10 (2007): 244-256. Print.

Attwood, Lynn. "The Post-Soviet Women in the Move to the Market: A Return to Domesticity and Dependence?" Women in Russia and Ukraine. Eds. Rosalind Marsh. Cambridge: Cambridge UP, 1996. Print.

Babchenko, Arkadii. “Territoriia voli." Snob. Beta. 15 Dec. 2013. Web. 7 July 2014. <http://www.snob.ru/selected/entry/69375>.

Bruder, Fraziska. "Den ukrainischen Staat erkämpfen oder sterben!" Die Organisation Ukrainischer Nationalisten (OUN) 1929-1948. Berlin: Metropol, 2007. Print.

Bureychak, Tetyana, and Petrenko, Olena. "Kanapky, Sich ta 'banderivky.' Zakhid.net. Web. 8 Jan. 2014 <http://zaxid.net/news/ showNews.do?kanapki_sich_ta_banderivki\&objectId=1300428>.

Bureychak, Tetyana. "Cossacks in Ukrainian Consumer Culture: New Old Masculinity Model." GEXcel Work in Progress Report VI: Proceedings from GEXcel Theme 2: Deconstructing the Hegemony of Men and Masculinities Conference 27-29 April 2009. Eds. Alp Biricik and Jeff Hearn. Linköping: Institute of Thematic Gender Studies, 2009. 215-26. Web. 16 June 2015. <http://www.gexcel.org/pdf/WiPR/GEXcel\%20Work\%20In\%20Progress 
\%20Vol\%20VI.\%20Proceedings\%20from\%20GEXcel\%20Theme\%202\%20 Deconstructing\%20the\%20Hegemony.pdf>.

---. "In Search of Heroes: Vikings and Cossacks in Present Sweden and Ukraine." NORMA. Nordic Journal for Masculinities Studies 7.2 (2012): 139169. Print.

---. "Zooming In and Out: Historical Icons of Masculinity Within and Across Nations." Rethinking Transnational Men: Beyond, Between and Within Nations. Routledge Advances in Feminist Studies and Intersectionality. Eds. Jeff Hearn, Katherine Harrison, Marina Blagojevic. New York: Routledge, 2013. Print.

Carrigan, Tim, Connell, Bob, and Lee, John. "Towards a New Sociology of Masculinity." Theory and Society 14.5 (1985): 551-604. Print.

Chermalykh, Natalia. "Feministychnyi analiz politychnoi pmalhamy mizh padykalnymy i pomirkovanymy natsionalistamy ta relihiinymy pravymy: Konservatyvnyi konsensus dovkola gendernykh ta minorytarnykh problematyk suchasnoi Ukrainy." Gender, relihiia i natsionalism v Ukraini. Ed. Halyna Iarmanova. Kyiv: Heinrich Böll Stiftung, 2012. 13-15. Print.

Connell, R. W. and James W. Messerschmidt. "Hegemonic masculinity. Rethinking the concept." Gender and Society 19.6 (2005): 829-859. Print.

Connell, R. W. Gender and Power: Society, the Person and Sexual Politics. Cambridge: Polity, 1987. Print.

Connell, R. W. Masculinities. Cambridge: Polity, 1995. Print.

"Doluchuitesia do material'noho zabezpechennia svobodivtsiv-biitsiv ATO." Vseukrains'ke ob"iednannia 'Svoboda.' Web. 15 April 2015. $<$ http://ato.svoboda.org.ua>.

Enloe, Cynthia. "All the Men Are in the Militias, All the Women Are Victims: The Politics of Masculinity and Femininity in Nationalist Wars." The Women \& War Reader. Ed. Lois Ann Lorentzen, and Jennifer Turpin. New York: New York UP, 1998: 50-62. Print.

Gendernyi monitoryng parlamentskykh vyboriv 2012 roku. Lutsk: VMA "Teren", 2012. Print.

Gilbert, Ernest, and Eric Helleiner. Nation-States and Money: The Past, Present, and Future of National Currencies. London: Routledge, 1999. Print.

Hrytsenko, Hanna. "Linzy Genderu dlia ukrains'kykh pravoradykaliv: prychyny, proiavy, naslidky." Gender, relihiia i natsionalism v Ukraini. Ed. Halyna Iarmanova. Kyiv: Heinrich Böll Stiftung, 2012. 125-149. Print.

Hymans, Jacques E. C. "International Patterns in National Identity Content: The Case of Japanese Banknote Iconography." Journal of East Asian Studies 5 (2005): 315-346. Print.

Hymans, Jacques E. C. "The Changing Color of Money: European Currency Iconography and Collective Identity." European Journal of International Relations 10.1 (2004): 5-31. Print.

Kappeler, Andreas. Die Kosaken. München: C.H. Beck, 2013. Print.

Kentii, Anatolii. Ukrains'ka Povstanska Armiia v 1942-1943 rokakh. Kyiv: NAN Ukrainy, 1999. Print. 
Kimmel, Michael S. "Globalization and Its Mal(e)contents: The Gendered Moral and Political Economy of Terrorism." International Sociology, 18.3 (2003): 603-620. Print.

Kis, Oksana. "Choosing Without Choice: Predominant Models of Femininity in Contemporary Ukraine." Gender Transitions in Russia and Eastern Europe. Eds. Asztalos Morell, Helene Carlbäck, Madeleine Hurd, and Sara Rastbäck. Stockholm: Gondolin, 2005. Print.

---. "Modeli konstruiuvannia identychnosti zhinky v suchasnii Ukraini." Yi 27 (2003): 109-119. Web. 7 July 2014. <http://www.ji.lviv.ua/ n27texts/>.

---. Zhinka $v$ tradytsiinii ukrains'kii kul'turi. Druha polovyna XIX - pochatok XX st. Lviv: Institute of Ethnology. Ukrainian Academy of Sciences. 2008. Print.

Kondratiuk, S. V. "Konstytutsiia Pylypa Orlyka: Ii zmist ta znachennia dlia utverdzhennya demokratychnyh zasad u suchasnomu derzhavotvorenni Ukrainy." Naukovyi visnyk l'vivs'kogo derzhavnoho universytetu vnutrishnikh sprav 4 (2009): 22-32. Print.

Kryvoshyi, Oleksandr. "Genderni vyklyky frontovoi povsiakdennosti kozats'koho Zaporizhia u naukovomu dorobku ukrianks'kykh istorykiv (1946-1991)." Ukrainoznavchyi Almanakh 11 (2013): 140-145. Print.

Kul'chyts'kyi, Serhii. Organizatsiia Ukrainskykh Natsionalistiv i Ukrains'ka Povstanska Armiia. Istorychni Narysy. Kyiv: Naukova dumka, 2005. Print.

Likhachev, Vyacheslav. "Right-Wing Extremism in Ukraine: The Phenomenon of Svoboda." Web. 10 February 2015 <http://library.eajc.org//data/image/ books/18/14/9/18149_d.pdf>.

Litopys Ukrainskoi Povstanskoi Armii. Vol. 1-50. Toronto: Litopys UPA, 19762013. Print.

Litopys UPA Online. Web. <http://www.litopysupa.com/main.php?pg $=1 \&$ series $=4>$.

Litopys UPA. Nova Seriia. Vol. 1-20. Kyiv: Institute of Ukrainian Archeography and Source Studies, 1995-2013. Print.

Luts'kyi, Oleksandr. Transcripts of investigations of member of Provid. 19-20 July 1945. HDA SBU [Haluzevyi Derzhavnyi Arkhiv Sluzhby Bezpeky Ukrainy (Branch State Archive, Security Services of Ukraine, Kyiv, Ukraine] f. 13 , spr. 372, t. 53, ar. 35. 18-20 August 2012. For online version, see: Elektronyi arkhiv ukrains'koho vyzvol'noho rukhu. <http://avr.org.ua/ index.php/viewDoc/21760/>.

Marples, David. "Anti-Soviet Partisans and Ukrainian Memory." East European Politics \& Societies 24.1 (2010): 26-43. Print.

Martseniuk, Tamara. “Gender i natsiia v ukrains'komu suspilstvi: maskulinnosti ta Evromaidan 2013-2014." Ia: gendernyi zhurnal 37.1 (2015): 4-9. Print.

Mayer, Tamar. Gender Ironies of Nationalism: Sexing the Nation. London: Routledge, 2002. Print.

Miahka, Hanna. "Rozvytok demokratychnyh tendentsiy v Zaporizh'kii Sichi i Het'manshchyni (druha polovyna XVII-pochatok XVIII stolittya." Avtoreferat dysertatsii na zdobuttia stupenia kandydat istorychnyh nauk. Natsional'na biblioteka Ukrainy. Web. 15 April 2015. <http://www.irbis-nbuv.gov.ua/cgibin/irbis_nbuv/cgiirbis_64.exe?I21DBN=ARD\&P21DBN=ARD\&Z21ID=\&S21 
$\mathrm{REF}=10 \& \mathrm{~S} 21 \mathrm{CNR}=20 \& \mathrm{~S} 21 \mathrm{STN}=1 \& \mathrm{~S} 21 \mathrm{FMT}=$ fullwebr\&C21COM=S\&2_S21P 03=K=\&2_S21STR=M'ЯГКА $>$.

Motyka, Grzegorz. Ukrainska Partyzantka 1942-1960: Dzialalnosc Organizacji Ukrainskich Nacjonalistow i Ukrainskiej Powstanczej Armii. Warsaw: Rytm, 2006. Print.

Mudde, Cas. "Three Decades of Populist Radical Right Parties in Western Europe: So What?" European Journal of Political Research 52 (2013): 1-19. Print.

Mudde, Cas. Populist Radical Right Parties in Europe. Cambridge: Cambridge UP, 2007. Print.

"Na Cherkaschyni natsionalisty provely smoloskypni marshi pam"iati heroiv Krut." 25 Jan. 2015. Web. 10 April 2015. <http://svoboda.org.ua/news/ events/00012632/>.

"Na poli Berestets'koi bytvy vidbulosia vshanuvannia polehlych kozakiv." Svoboda. Rivne. Ofitsiina storinka. 8 July 2013. Web. 10 February 2014. <http://www.rivne.svoboda.org.ua/diyalnist/novyny/040699/>.

Nagel, Joane. "Masculinity and Nationalism: Gender and Sexuality in the Making of Nations." Ethnic and Racial Studies 21.2 (1998): 242-269. Print.

“Natsional'na Konstytutsiia (proekt VO 'Svoboda')." Svoboda. Diaspora. Ofitsiina storinka. Web. 15 April 2014. <http://www.diaspora.svoboda.org.ua/ pro_partiyu/prohrama/konstytutsiya/>.

"Natsionalisty 'pokaraly zbochentsiv-pederastiv' za aktsiiu 'Anty-Yolka' v Kyevi." TSN.UA. 13 Dec. 2010. Web. 1 April 2015. <http://tsn.ua/ ukrayina/nacionalisti-pokarali-zbochenciv-pederastiv-za-akciyu-anti-yolkav-kiyevi.html>.

"Natsionalisty vitaly odesytok z Dnem materi." Svoboda. Odesa. Ofitsiina storinka. Web. 10 April 2015. <http://www.odesa.svoboda.org.ua/ diyalnist/novyny/014860/>.

Neubert, Claudia. Nationsbildung in der Ukraine und die Figur Ivan Mazepas: ein Moderner Mythos zur Konstruktion Kollektiver Identität? Berlin: LIT Verlag, 2008. Print.

Onuch, Olga, and Tamara Martsenyuk. "Mothers and Daughters of the Maidan: Gender, Repertoires of Violence, and the Division of Labour in Ukrainian protests." Social, Health, and Communication Studies Journal (Contemporary Ukraine: A case of Euromaidan) 1.1 (2014): 80-101. Print.

Onyshko, Lesia. "Nam sontse vsmikhalos' kriz' rzhavii graty..." Kateryna Zaryts'ka v ukrains'komu natsional'no-vyzvol'nomu rusi. Toronto: Litopys UPA, 2007. Print.

Petrenko, Olena. "Literaturni insynuatsii. Radians'ka prosa pro 'banderivok' ta ikh pobornyts." Ukraina Moderna.com. 15 Dec. 2013. Web. 2 Sept. 2014 $<$ http://uamoderna.com/blogy/olena-petrenko/li-1>.

Phillips, Sarah. "The Women's Squad in Ukraine's Protests: Feminism, Nationalism, and Militarism on the Maidan." American Ethnologist 41.3 (2014): 414-426. Print.

Plokhy, Serhii. The Cossacks and Religion in Early Modern Ukraine. Oxford, NY: Oxford UP, 2001. Print.

Posivnych, Mykola. Neskorenyi Komandyr. Toronto: Vydavnytstvo "Litopys UPA," 2007. Print. 
Posivnych, Mykola. Roman Shukhevych. Kyiv: Atlant-UMS, 2007. Print.

"Pro batal'ion." Batal'ion Sich. Web. 15 April 2015. <http://www.battalionsich.info/pro-batalyon>.

"Prohrama VO 'Svoboda'-Prohrama zakhystu ukraintsiv." Vseukrains'ke ob"iednannia "Svoboda" Ukraina. Ofitsiina storinka. Web. 10 June 2014. <http://svoboda.org.ua/party/program/>.

"Rezolutiya Z"izdu VO «Svobody» shchodo vzhyttia nehainykh krokiv protydii Rosiys'kii ahresii." Vseukrains'ke ob"iednannia "Svoboda". Ukraina. Ofitsiina storinka. 9 Feb. [2015]. Web. 10 April 2015. <http://svoboda.org.ua/ news/documents/00012746/>.

Rubchak, Marian, J. "Christian Virgin or Pagan Goddess: Feminism Versus the Eternally Feminine in Ukraine." Women in Russia and Ukraine. Ed. Rosalind Marsh. Cambridge: Cambridge UP, 1996. Print.

Rudling, Per. "The OUN, the UPA and the Holocaust: A Study in the Manufacturing of Historical Myths." The Carl Beck Papers in Russian and East European Studies 2107 (2011). Pittsburgh: University Center for Russian and East European Studies, 2011. Print.

Saltovs'kyi, Oleksandr. Kontseptsii ukrains'koi derzhavnosti v vstorii vitchyznianoi polititychnoi dumky (vid vytokiv do pochatku XX storichchia). Kyiv: Parapan, 2002. Izbornyk. Web. 10 April 2014. <http://litopys.org.ua/salto/salt.htm>.

Serhiichuk, Volodymyr. Roman Shukhevych v dokumentakh radians'kykh orhaniv derzhavnoi bezpeky (1940-1950). Kyiv: PP Serhiichuk M.I., 2007. Print.

Shekhovtsov, Anton. "Vseukrainskoe Obyedinenie "Svoboda": Problema Legitimnosti Bor'by za Vlast'." Forum noveisheyi vostochnoevropeiskoi istorii i kultury 10.1 (2011): 22-63. Print.

Shevel, Oksana. "The Politics of Memory in a Divided Society: A Comparison of Post-Franco Spain and Post-Soviet Ukraine." Slavic Review 70.1 (Spring 2011): 137-164. Print.

Shtokalo, Vasyl', and Bohdan Trofymiak. Roman Shukhevych na tli doby voiuiuchoi Ukrainy. Ternopil: Ideia ta chyn, 2005. Print.

"Sud zalyshyv Banderu i Shukevycha bez zvan' heroia." Ukrains'ka pravda. Istorychna Pravda. 2 Aug. 2011. Web. 7 July 2014. <http:// www.istpravda.com.ua/short/2011/08/2/48527/>.

Tolz, Vera, and Stephenie Booth. Nation and Gender in Contemporary Europe. Manchester: Manchester UP, 2005. Print.

Tys-Krokhmaliuk, Yurii. UPA Warfare in Ukraine. Strategical, Tactical and Organizational Problems of Ukrainian Resistance in World War II. sNew York: Society of Veterans of Ukrainian Insurgent Army, 1972. Print.

Umland, Andreas, and Anton Shekhovtsov. "Ultra-Right Party Politics in PostSoviet Ukraine and the Puzzle of the Electoral Marginalism of Ukrainian Ultranationalists in 1994-2009." Russian Politics and Law 51.5 (2013): 3358. Print.

"V 'Svobode' zaiavlyaiut, chto v ES nuzhno idti bez propagandy gomosexualizma." UNIAN. 24 Aug. 2013. Web. 10 April 2015 <http:// www.unian.net/politics/826413-v-svobode-zayavlyayut-chto-v-es-nujnoidti-bez-propagandyi-gomoseksualizma.html>. 
Viedienieiev, Dmitrii. Odisseia Vasyliia Kuka. Voenno-politicheskii portret poslednego komanduiushhego UPA. Kyiv: K.I.C., 2007. Print.

Viedienieiev, Dmytro, and Henadii Bystrukhin. Dvobii bez kompromisiv. Protyborstvo spetsrozdiliv OUN ta radians'kykh syl spetsoperatsii. Kyiv: K.I.C., 2007. Print.

“Vybory Narodnykh Deputativ 28 zhovtnia 2012." Tsentral'na vyborcha komisiia. Web. 1 March 2014. <http://www.cvk.gov.ua/vnd_2012/>.

Watson, Peggy. "Eastern Europe Silent Revolution: Gender." Sociology 27.3 (1993): 471-487. Print.

Wilson, Andrew. Ukrainian Nationalism in the 1990s: a Minority Faith. Cambridge: Cambridge UP, 1997. Print.

Yekelchyk, Serhy. "Bridging the Past and the Future: Ukrainian History Writing Since Independence." Canadian Slavonic Papers / Revue Canadienne des Slavistes 53. 2/4 (June-Sept.-Dec. 2011): 559-573. Print.

---. Stalin's Empire of Memory: Russian-Ukrainian Relations in the Soviet Historical Imagination. Toronto: University of Toronto Press, 2004. Print.

Yuval-Davis, Nira. Gender and Nation. London: Sage, 1997. Print.

Zdravomyslova, Elena and Anna Temkina. "Sovetskii etakraticheskii gendernyi poriadok." Rossiyskiy gendernyi poriadok: soysiologicheskii podkhod Eds. Elena Zdravomyslova and Anna Temkina. Saint-Petersburg: Publishing House of European University. 2007. 96-137. Print. 
(c) 2015 East/West: Journal of Ukrainian Studies (ewjus.com) ISSN 2292-7956 Volume II, No. 2 (2015) 